\title{
Accelerated ripening of reduced fat semi-hard cheese from a mixture of cow's, goat's and ewe's ultrafiltrated milk by using a Lac ${ }^{-}$Prt $^{-}$strain of lactococci
}

\author{
J Rodríguez ${ }^{1}$, T Requena ${ }^{1 *}$, H Goudédranche², \\ JL Maubois², M Juárez ${ }^{1}$ \\ ${ }^{1}$ Instituto del Frío (CSIC), Ciudad Universitaria, 28040 Madrid, Spain; \\ ${ }^{2}$ Laboratoire de recherches de technologie laitière, Inra, 65, rue de Saint-Brieuc, \\ 35042 Rennes cedex, France
}

(Received 13 May 1996; accepted 6 August 1996)

\begin{abstract}
Summary - The technological process for a reduced fat ( $360 \mathrm{~g} / \mathrm{kg}$ total solids) semi-hard cheese, based on a mixture of cow's, ewe's and goat's milk concentrated by ultrafiltration, was assayed using starter cultures,designed to accelerate proteolysis and improve flavour and aroma development. The proteolytic fractions studied (noncasein nitrogen, nonprotein nitrogen and amino nitrogen) were significantly higher in the cheeses elaborated with the selected starter (IFPL) towards a commercial starter (Flora Danica). The addition to the IFPL starter of a Lactococcus lactis subsp lactis Lac ${ }^{-} \mathrm{Prt}^{-}$ strain (T1) caused, at the end of the cheese ripening time ( 3 months), a two-fold increase in the amino nitrogen content, when compared to the cheeses elaborated with the commercial starter. The reduced fat ultrafiltrated (UF) milk cheeses elaborated with IFPL starter achieved an adequate proteolysis together with the right balance of flavour and aroma. By using a starter culture previously selected for semi-hard cheeses, and enhanced by addition of $\mathrm{Lac}^{-} \mathrm{Prt}^{-}$lactococci, it was possible to accelerate in $11 / 2$ months the ripening time required for the UF cheeses made with a commercial starter.
\end{abstract}

\section{reduced fat cheese / ultrafiltrated milk / accelerated cheese ripening / mutant lactococci/starter}

Résumé - Affinage accéléré de fromage à pâte demi-dure, à teneur en matière grasse réduite, obtenu à partir d'un lait de mélange vache-chèvre-brebis ultrafiltré, à l'aide de lactocoques Lac-, Prt. La technologie de fabrication d'un fromage à pâte demi-dure, à teneur en matière grasse réduite ( $360 \mathrm{~g} / \mathrm{kg}$ d'extrait sec) obtenu à partir d'un mélange de lait de vache, de chèvre et de brebis ultrafiltré (UF) a été expérimentée. Des levains destinés à accélérer la protéolyse et à améliorer le développement de la flaveur et de l'arôme ont été utilisés. Les teneurs en azote des fractions protéolysées étudiées (azote non caséique, azote non protéique, azote aminé) étaient significativement plus élevées dans les fromages élaborés avec le levain sélectionné (IFPL) que dans les fromages élaborés avec un levain commercial (Flora Danica). L'addition d'une souche de Lactococcus lactis subsp lactis Lac Prt (T1) au levain IFPL provoquait à la fin de l'affinage (3 mois) un doublement de l'augmentation

* Correspondence and reprints. 
du taux d'azote aminé des fromages, comparativement à ceux élaborés avec le levain commercial. Les fromages à teneur en matière grasse réduite élaborés à partir de lait ultrafiltré avec des levains IFPL, parvenaient à une bonne protéolyse, tout en ayant un juste équilibre de flaveur et d'arôme. L'utilisation de levains choisis pour des fromages à pâte demi-dure et améliorés par l'addition de lactocoque Lac Prt réduisait d'un mois et demi le temps nécessaire à l'affinage des fromages ultrafiltrés fabriqués avec un levain commercial.

fromage à matière grasse réduite / lait ultrafiltré / accélération de l'affinage des fromages / lactocoque Lac $^{-} \mathrm{Prt}^{-}$/ levain

\section{INTRODUCTION}

Low fat cheeses made under conventional conditions normally present defective sensory characteristics, for example weak aroma, unwanted flavours and over-firm or rubbery texture (Jameson, 1994). There may be a number of causes to these defects: low fat levels (which are a factor in dissolution of aroma compounds and masking of flavours, such as a bitter taste), lower degree of lipolysis, altered protein matrix density and too little or too much proteolysis depending on the characteristics of the manufacturing process. Moreover, in this kind of product, bitter peptides, which form as caseins break down under the action of the rennet and the proteases from the microorganisms in the starter culture, are more evident owing to the smaller proportion of the aroma compounds which grow in the presence of fats (EI Soda, 1993).

In an effort to achieve products with acceptable characteristics, proposals have been made for modified cheesemaking techniques and the introduction of technological innovations, with the following objectives: to retain more moisture in the three-dimensional casein network, so as to compensate for the reduction in fat; and to control the salt/moisture ratio and improve the aroma through the use of lactic bacteria either as part of or in addition to the starter culture (Ardö, 1994; Emmons, 1994). Fat substitutes such as modified starch, structured lipids, sucrose polyesters, and so on have also been used as fat replacers in cheeses (Quiblier et al, 1990; Drake and Swanson, 1995).

A variety of alternatives have been tried to control cheese moisture, but it is not known by how much the moisture in low fat cheeses needs to be increased for the product to be as similar as possible to a traditional cheese in terms of firmness and texture (Emmons, 1994). A number of authors have proposed the use of ultrafiltrated (UF) milk concentrate to retain more moisture in low fat cheeses (Boer and Nooy 1980; De Koning et al, 1981; Ardö, 1994). However, there are problems to be solved arising from the slowdown of ripening due to lower levels of residual rennet, the presence of protease and peptidase inhibitors and the ability of whey proteins to link with some aroma compounds (Lelievre and Lawrence, 1988; Bech, 1993).

A number of proposals have been made to improve aroma and flavour in low fat cheeses: the use of enzymes such as commercial aminopeptidases (Coulson et al, 1992; Skeie et al, 1995), mixtures of proteases and lipases (McGregor and White, 1990), the addition of heat-treated microorganisms (Ardö et al, 1989; Ardö and Mansson, 1990; El Soda et al, 1991) or the use of modified starter cultures. Lactococci Prt Lac- (Grieve and Dulley, 1983; Kamaly et al, 1989), Lac- (Birkeland et al, 1992) or Prt (Broome et al, 1991) have been used as adjuncts to the starter to improve the organoleptic characteristics of cheeses.

A specific starter culture for industrial production of semi-hard goat's milk cheese has been developed at our laboratory 
(Requena et al, 1992). In addition, the acidifying and proteinase activity of the strain Lactococcus lactis subsp lactis IFPL 359 in the new starter culture has been successfully eliminated, through loss of the plasmid where the genetic determinants that encode for these activities are located, while maintaining peptidase activity (Requena and McKay, 1993). It has been found that high concentrations of $L$ lactis subsp lactis IFPL 359, variant $\mathrm{Lac}^{-} \mathrm{Prt}^{-}$, accelerate proteolysis and hence flavour development in cheese slurries (Rodríguez et al, 1996).

The production of ewe's and goat's milk is growing in Spain. An important part of this production is used for the elaboration of semi-hard cheeses in a mixture with cow's milk. The production of these types of cheeses in Spain was approximately $140000 t(50 \%$ of the total cheese production) in 1994 (Federación Nacional de Industrias Lácteas [FENIL], 1996, personal communication).

The aim of the present work was to study the manufacturing process for a reduced fat semi-hard cheese based on a mixture of cow's, ewe's and goat's milk concentrated by ultrafiltration, using starter cultures designed to accelerate proteolysis and improve flavour and aroma.

\section{MATERIALS AND METHODS}

\section{Ultrafiltration process}

Approximately $190 \mathrm{~kg}$ of semi-skimmed milk (2.3\% fat content) made from skimmed cow's milk mixed with ewe's and goat's milk (55/15/30) was pasteurized $\left(4 \mathrm{~s}\right.$ at $\left.92^{\circ} \mathrm{C}\right)$ in an ACTIJOULE apparatus (Actini, Maxilly, Évian-les-Bains, France), at a flow rate of $500 \mathrm{~L} / \mathrm{h}$. After pasteurization, the milk was cooled to $50^{\circ} \mathrm{C}$ then put through the ultrafiltration process. A Tech Sep tubular apparatus was used (Tech Sep, SaintMaurice de Beynost, Miribel, France); its characteristics are described in an earlier paper (Goudédranche et al, 1980). The equipment consisted of two mineral-type subunits in zircone oxide $\left(\mathrm{ZrO}_{2}\right)$ which gave a total unit membrane area of $0.815 \mathrm{~m}^{2}$ (cut off $150000 \mathrm{Da}$ ). The pro- cess conditions were as follows: input pressure 4.4 bar, output pressure 3.0 bar, temperature $50^{\circ} \mathrm{C}$, flow rate $15000 \mathrm{~L} / \mathrm{h}$. Once a threefold concentration was attained, diafiltration was carried out, with the addition of sufficient water at $50^{\circ} \mathrm{C}$, to reduce lactose content in the retentate (down to $1.7 \%$ ).

Ultrafiltration was continued until total protein content in the retentate reached $226 \mathrm{~g} / \mathrm{kg}$, equivalent to a six-fold concentration.

\section{Preparation of cheeses}

Cheeses were made following the procedure described by Goudédranche et al (1980). Upon completion of ultrafiltration, the concentrate was cooled to $30^{\circ} \mathrm{C}$. When this temperature was reached, the various freeze-dried starter cultures were added directly to the vat to produce counts in the region of $10^{10} \mathrm{cfu} / \mathrm{kg}$ in the retentate.

Three batches of cheese were made using the following starter cultures: the commercial starter (Flora Danica MSP, Chr Hansen, Denmark), consisting of a mixture of $L$ lactis subsp cremoris, L lactis subsp lactis, Leuconostoc mesenteroides subsp cremoris and $L$ lactis subsp diacetylactis; the IFPL starter, previously described by Requena et al (1992), consisting of a mixture of L lactis subsp lactis IFPL 359 (80\%), Lactobacillus casei subsp casei IFPL 731 (5\%), L plantarum IFPL $935(5 \%), L$ mesenteroides subsp dextranicum IFPL $709(5 \%)$ and $L$ paramesenteroides IFPL 705 (5\%); and the IFPL starter, to which a concentrate of the Lac-Prt derivate of $L$ lactis subsp lactis IFPL 359 , strain $\mathrm{T} 1$, (approx $10^{10} \mathrm{cfu} / \mathrm{kg}$ retentate) was also added.

The freeze-dried cultures were re-dissolved in permeate $3 \mathrm{~h}$ before they were added to the retentate at $30^{\circ} \mathrm{C}$. Following starter addition, the pre-cheese ( $\mathrm{pH} \mathrm{6.58)}$ was left to acidify for $3 \mathrm{~h}$ at $30^{\circ} \mathrm{C}$. In this time $\mathrm{pH}$ dropped to 6.4 , at which point salt $(1.1 \% ; \mathrm{w} / \mathrm{w})$ and rennet $(0.4 \mathrm{~mL} / \mathrm{kg}$ precheese; rennet contained $520 \mathrm{mg} / \mathrm{L}$ of chymosin) were added.

Approximately $600 \mathrm{~g}$ of cheese were placed in moulds and left to acidity overnight in a chamber at $30^{\circ} \mathrm{C}$, until pH reached approximately 5 . The moulds were then placed in ripening chambers at $13{ }^{\circ} \mathrm{C}$ and $90 \%$ relative humidity. After $3 \mathrm{~h}$ in these conditions, the cheeses were removed from their moulds and treated with a solution of $3 \mathrm{~g} / \mathrm{L}$ of Delvocid (Gist-brocades nv, Seclin, France) to prevent growth of fungi during ripe- 
ning, which took place over 3 months. Cheese samples were taken in triplicate at $0,15,30,45$, 60 and 90 days of ripening.

\section{Physicochemical analysis}

Dry matter, total protein, fat and lactose content of milk in permeates and serum were determined using a MULTISPEC apparatus (Föss Electric, Nanterre, France). The $\mathrm{pH}$ was measured directly in milk and cheeses using a Schott CG-837 pH meter.

Total solids (TS) and fat were determined according to the International Dairy Federation standards (IDF, 1982 and 1986, respectively). Nitrogen and total protein were determined by the Kjeldahl procedure (Official Methods of Analysis, 1975). Noncasein nitrogen (NCN) and nonprotein nitrogen (NPN) were determined by the procedure described by Kuchroo and Fox (1982), and the amino nitrogen fraction ( $\mathrm{N}^{\left.-\mathrm{NH}_{2}\right)}$ by the method described by Kuchroo et al (1983).

$\mathrm{Ca}$ and $\mathrm{Mg}$ contents were determined by atomic absorption spectrophotometry following precipitation with trichloroacetic acid (De la Fuente and Juárez, 1995b). P was determined colorimetrically following the method described by $\mathrm{De}$ la Fuente and Juárez (1995a).

\section{Microbiological analyses}

Sample-taking and the necessary dilutions were carried out in accordance with the International Dairy Federation standards (IDF, 1985). Total viable counts of lactobacilli and leuconostocs were performed following the procedures previously used by Gómez et al (1989). Lactococcal differentiation was carried out on agar plates using bromocresol purple as lactose fermentation indicator (McKay et al, 1970).

\section{Sensory analysis}

Cheeses were subjected to periodic sensory analysis throughout ripening $(15,30,45,60$ and 90 days), following the recommendations of the International Dairy Federation (IDF, 1987). The attributes assessed were: general appearance, aroma, flavour/taste, texture and general acceptability, for each of which the cheeses were awarded points on a scale of 1 (very poor) to 5 (very good). Defects in flavour or aroma were also evaluated.

\section{Statistical analysis}

Statistical study consisted of a two-way analysis of variance carried out using BMDP programs

Table I. Composition of cow's, ewe's and goat's milk and the mixture used in the ultrafiltration process and of the permeates and the retentate.

Composition des laits de vache, brebis et chèvre, et du lait de mélange soumis à l'ultrafiltration, ainsi que des perméats et du rétentat.

\begin{tabular}{|c|c|c|c|c|c|}
\hline & Fat $(g / L)$ & $\begin{array}{c}\text { Protein } \\
(g / L)\end{array}$ & $\begin{array}{c}\text { Lactose } \\
(g / L)\end{array}$ & Dry matter $(g / L)$ & $p H$ \\
\hline \multicolumn{6}{|l|}{ Milk } \\
\hline Cow (C) & 0.9 & 36.6 & 48.1 & 93.5 & - \\
\hline Goat (G) & 32.9 & 30.4 & 45.9 & 114.7 & - \\
\hline Ewe (E) & 79.5 & 60.9 & 46.1 & 196.6 & - \\
\hline $\begin{array}{l}\text { Mixture C/E/G } \\
(55 / 15 / 30)\end{array}$ & 22.7 & 38.5 & 48.6 & 116.6 & 6.7 \\
\hline \multicolumn{6}{|l|}{ Permeate } \\
\hline Before diafiltration & 0.0 & 2.2 & 50.7 & 54.9 & - \\
\hline At the end of UF & 0.0 & 2.1 & 25.3 & 27.3 & - \\
\hline Mixture permeate & 0.0 & 1.9 & 37.3 & 40.1 & - \\
\hline Retentate & 132.0 & 226.0 & 17.0 & 399.0 & 6.6 \\
\hline
\end{tabular}


2D, $2 \mathrm{~V}$ and 7D (version 1994) on an ALPHA 2100 under VMS computer (CTI CSIC, Madrid, Spain).

\section{RESULTS AND DISCUSSION}

\section{Ultrafiltration process}

The characteristics of milk, permeate and retentate composition are shown in table I. The milk mixture used to make the cheeses contained $2.3 \%$ fat, $3.8 \%$ protein, $4.9 \%$ lactose and $11.7 \%$ total solids.

From an initial $190 \mathrm{~kg}$ of milk, total permeate after ultrafiltration was $228 \mathrm{~kg}$. This gives a yield for the process of $16.3 \%$, since the volume of whey left after making the cheeses was approximately $2 \%$. Total protein content in the whey was $5.6 \%$ and total solids $11.2 \%$.

Total $\mathrm{Ca}, \mathrm{Mg}$ and $\mathrm{P}$ contents in the milk were $1184 \pm 20,134 \pm 1$ and $1040 \pm 20 \mathrm{mg} / \mathrm{kg}$, respectively, and in the permeate $204 \pm 4$, $64 \pm 1$ and $210 \pm 25 \mathrm{mg} / \mathrm{kg}$, giving a percentage of retention in the retentate of $85.00,58.50$ and $82.45 \%$, respectively. Percent retention of $\mathrm{Ca}$ in the retentate was higher than that reported by Brule et al (1974) in UF milk and Qvist et al (1987) in Havarti cheese made with UF milk, probably because the milk was not acidified prior to the ultrafiltration process, so that less $\mathrm{Ca}$ entered the soluble phase (Holt, 1985).

\section{Evolution of physicochemical characteristics of cheeses in the course of ripening}

Fat and protein contents (as a proportion of TS) did not change to any appreciable extent during ripening of all batches, nor were they affected by the different starters used. Mean values were $(\mathrm{g} / \mathrm{kg}$ TS) fat $360.4 \pm 1.68$ and protein $533.3 \pm 2.99$. Protein content (\%TS) was higher than that reported by Goudédranche et al (1980) for UF Saint-Paulin cheese, by El-Shibiny et al (1991) for UF Ras cheese and by Qvist et al (1987) for UF Havarti cheese, owing to the reduced fat content in the milk used. Fat content was around $40 \%$ lower than in a traditional semi-hard ewe's or goat's milk cheese (Martín Hernández et al, 1992; Fontecha et al, 1994).

Figure 1 shows the evolution of $\mathrm{pH}$ and total solids in the course of ripening for all three cheese batches. The mean $\mathrm{pH}$ value of the cheeses at the outset of ripening was 5.0 , approximately $1.5 \mathrm{pH}$ units lower than the original milk, and was similar to that
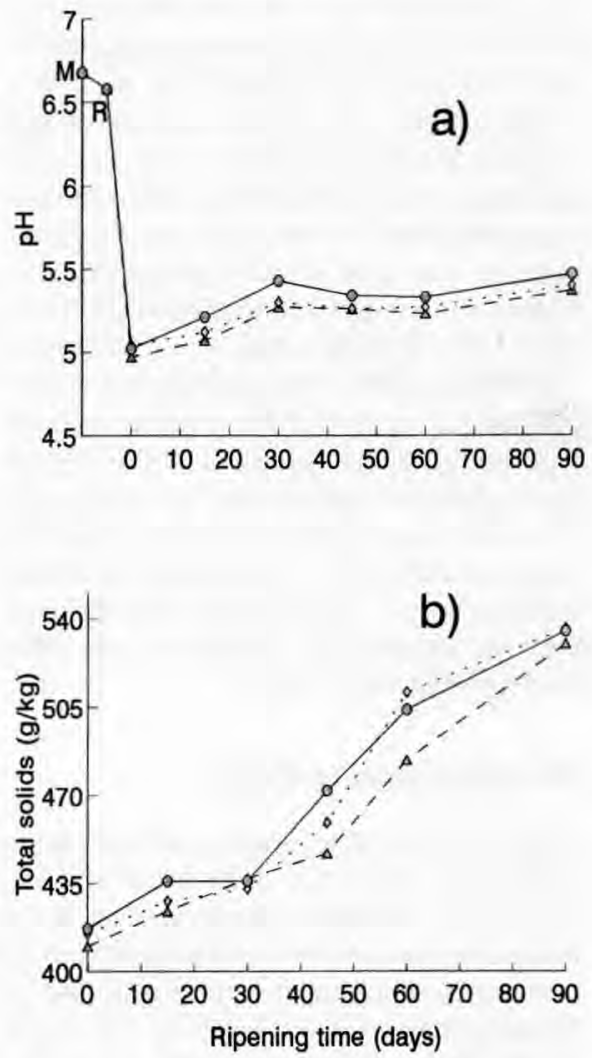

Fig 1. Evolution of (a) $\mathrm{pH}$ and (b) total solids in cheeses elaborated with the Flora Danica starter (O), IFPL starter $(0)$ and IFPL + T1 $(\Delta)$ during ripening. M: milk; $\mathrm{R}$ : retentate.

Evolution a) du $\mathrm{pH}$ et b) de la matière sèche totale de fromages élaborés avec des levains Flora Danica (O), IFPL $(0)$ et IFPL + T1 $(\Delta)$ durant l'affinage. (M) lait. $(R)$ rétentat. 
reported by Delbeke (1987) for UF SaintPaulin cheese, Spangler et al (1989) for UF Gouda cheese and McGregor and White (1990) for low fat Cheddar cheese. The $\mathrm{pH}$ during the first 45 days of ripening was significantly lower in the IFPL batches $(P<0.01)$. The addition of $L$ lactis $\mathrm{Lac}^{-} \mathrm{Prt}$ (T1) again produced no lowering of $\mathrm{pH}$, as might have been expected as a result of loss of phospho- $\beta$-galactosidase activity (Requena and McKay, 1993). At the end of the ripening period, the $\mathrm{pH}$ in all batches was 5.4. Evolution of $\mathrm{pH}$ was similar to that found in UF Saint-Paulin and UF Camembert cheeses (Goudédranche et al, 1986).

Figure 1 also shows the evolution of total solids in the three batches in the course of ripening. Total solids at the outset of ripening were low (mean value for the three batches was $41.4 \%$ ) as compared to other cheeses made with ultrafiltrated milk (Qvist et al, 1987; Spangler et al, 1989; McGregor and White, 1990). This could be due to both the low fat content of the cheeses and the high temperature treatment of the original milk and hence high levels of moisture were retained, even after 3 months' ripening (mean value $53.3 \%$ ). Total solids increased during cheese ripening and the evolution was not significantly affected by the different types of starter used.

\section{Microbiological analyses}

Figure 2 shows the evolution of total microorganisms, lactococci, lactobacilli and leuconostocs over the ripening period in the three cheese batches. The evolution of total counts was similar to that reported by Goudédranche et al (1986) in UF SaintPaulin cheese. Lactococci were the predominant flora in all batches and at all stages of the assay, although counts were lower in cheeses made with Flora Danica than those made with IFPL starter. Lactococci counts declined over the storage period, and by the end were either two logarithmic units (cheeses with Flora Danica) or one logarithmic unit (IFPL starter) lower than the initial values. Over the same period, counts of $L$ lactis subsp lactis T1 fell by two logarithmic units (results not shown). Hi-

a)

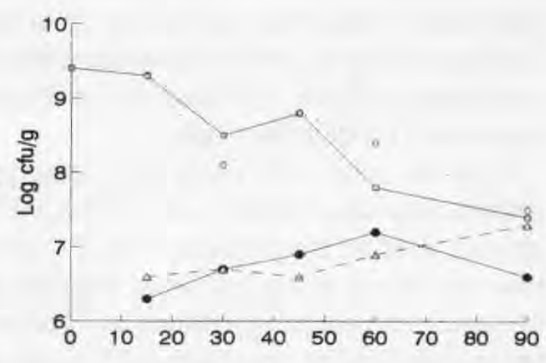

b)

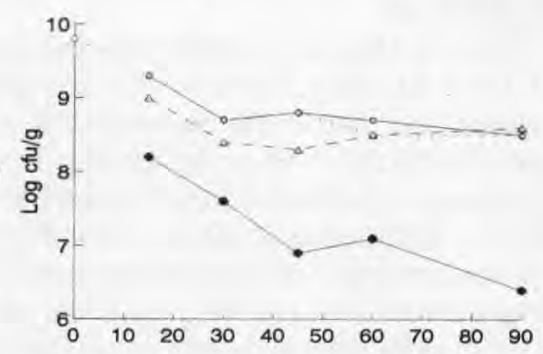

c)

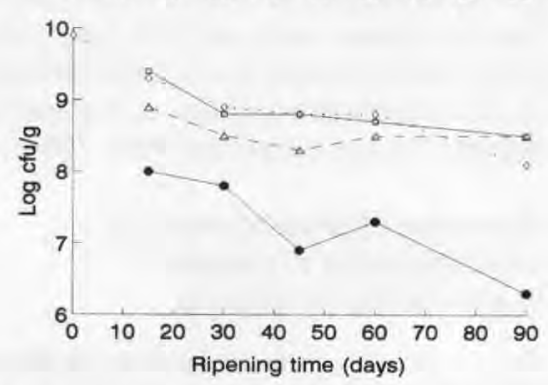

Fig 2. Evolution of the total viable microorganisms $(\square)$, lactococci $(0)$, lactobacilli $(\Delta)$ and leuconostoc (ब) in cheeses elaborated with (a) Flora Danica starter, (b) IFPL starter and (c) IFPL starter $+T 1$ during ripening $(0,15,30,45,60$ and 90 days).

Évolution de la flore mésophile aérobie revivifiable (), lactocoque (0), lactobacille ( $\Delta$ ) et leuconostoc (-) dans les fromages élaborés avec des levains (a) Flora Danica, (b) IFPL et (c) IFPL + $T 1$, durant l'affinage $(0,15,30,45,60$ et 90 jours). 
gher levels of lysis have been found for this variant Lac- Prt (Rodríguez et al, 1996).

At the end of the ripening period, lactococci and lactobacilli counts were similar in cheeses made with IFPL starter or Flora Danica. In the latter case, these were probably originated by milk contamination during manufacturing and were significantly lower than in IFPL cheeses. Leuconostoc levels were higher in IFPL cheeses than in those made with Flora Danica at all stages of the assay (fig 2).

\section{Nitrogen fractions}

Evolution of the nitrogen fractions (NCN, NPN and $\mathrm{N} . \mathrm{NH}_{2}$ ) in the three cheese batches is shown in table II. NCN content in the three batches increased significantly $(P<0.05)$ over the first 2 weeks of ripening, and slightly thereafter. The highest NCN values were obtained in the cheeses elaborated with $L$ lactis $T 1$ in the starter culture (table II). Evolution of NPN was comparable to that of NCN in all three batches.

The most significant differences between batches were found in the $\mathrm{N}^{-\mathrm{NH}_{2}}$ fraction, which increased more sharply $(P<0.05)$ during ripening of cheeses made with IFPL starter than with Flora Danica (table II). By the end of the ripening period, the level of amino nitrogen was higher $(P<0.001)$ in the IFPL batches than in the Flora Danica ( 2.83 and $3.22 \%$ as compared to $1.62 \%$ ). Moreover, the amino nitrogen content of cheeses after 90 days of ripening increa-

Table II. Mean values and standard deviation (in parenthesis) for the nitrogen fractions: noncasein nitrogen (NCN), nonprotein nitrogen (NPN) and amino nitrogen $\left(\mathrm{N}^{\mathrm{N}} \mathrm{NH}_{2}\right)$ in cheeses during ripening. Teneurs moyennes et écarts types (entre parenthèses) des fractions azotées : azote non caséique (NCN), azote non protéique (NPN) et azote aminé (N.NH2) des fromages au cours de l'affinage.

\begin{tabular}{lcccc}
\hline $\begin{array}{l}\text { Cheese } \\
\text { batch }\end{array}$ & $\begin{array}{c}\text { Ripening } \\
\text { time (days) }\end{array}$ & $\begin{array}{c}\text { NCN } \\
(\% \text { TN) }\end{array}$ & $\begin{array}{c}\text { NPN } \\
(\% T N)\end{array}$ & $\begin{array}{c}\text { N.NH2 } \\
(\% T N)\end{array}$ \\
\hline & 0 & $11.7(0.0)^{\mathrm{a}}$ & $5.1(0.0)^{\mathrm{a}}$ & $0.08(0.0)^{\mathrm{a}}$ \\
Flora & 15 & $18.4(0.0)^{\mathrm{b}}$ & $11.0(0.5)^{\mathrm{a}}$ & $0.12(0.0)^{\mathrm{b}}$ \\
Danica & 30 & $18.1(0.1)^{\mathrm{b}}$ & $14.9(0.6)^{\mathrm{a}}$ & $0.31(0.1)^{\mathrm{b}}$ \\
starter & 45 & $22.3(0.2)^{\mathrm{a}}$ & $14.5(0.1)^{\mathrm{a}}$ & $1.07(0.1)^{\mathrm{c}}$ \\
& 60 & $25.1(0.3)^{\mathrm{b}}$ & $16.3(0.2)^{\mathrm{a}}$ & $1.51(0.3)^{\mathrm{b}}$ \\
& 90 & $25.2(0.2)^{\mathrm{b}}$ & $16.5(0.3)^{\mathrm{b}}$ & $1.62(0.1)^{\mathrm{c}}$ \\
IFPL & 0 & $11.3(0.1)^{\mathrm{a}}$ & $3.6(0.1)^{\mathrm{b}}$ & $0.09(0.0)^{\mathrm{a}}$ \\
starter & 15 & $19.5(0.1)^{\mathrm{a}}$ & $12.4(0.5)^{\mathrm{a}}$ & $0.34(0.0)^{\mathrm{ab}}$ \\
& 30 & $20.6(0.3)^{\mathrm{ab}}$ & $14.6(0.8)^{\mathrm{a}}$ & $0.94(0.1)^{\mathrm{a}}$ \\
& 45 & $24.3(0.2)^{\mathrm{a}}$ & $17.8(0.3)^{\mathrm{a}}$ & $1.52(0.4)^{\mathrm{b}}$ \\
& 60 & $25.6(0.2)^{\mathrm{ab}}$ & $17.6(0.7)^{\mathrm{a}}$ & $2.62(0.5)^{\mathrm{a}}$ \\
IFPL & 90 & $25.7(0.1)^{\mathrm{ab}}$ & $20.4(0.2)^{\mathrm{a}}$ & $2.83(0.2)^{\mathrm{b}}$ \\
starter + & 0 & $11.5(0.1)^{\mathrm{a}}$ & $4.0(0.0)^{\mathrm{b}}$ & $0.08(0.0)^{\mathrm{a}}$ \\
T1 & 15 & $19.4(0.1)^{\mathrm{a}}$ & $13.7(0.5)^{\mathrm{a}}$ & $0.38(0.1)^{\mathrm{a}}$ \\
& 30 & $22.0(0.3)^{\mathrm{a}}$ & $16.1(0.7)^{\mathrm{a}}$ & $1.27(0.3)^{\mathrm{a}}$ \\
& 45 & $24.1(0.2)^{\mathrm{a}}$ & $17.5(0.7)^{\mathrm{a}}$ & $1.86(0.2)^{\mathrm{a}}$ \\
& 60 & $27.5(0.2)^{\mathrm{a}}$ & $17.4(0.5)^{\mathrm{a}}$ & $2.49(0.4)^{\mathrm{a}}$ \\
\hline
\end{tabular}

$a, b, c$ Means at the same time ripening time not follewed by the same letter differ significantly $(P<0.05)$. Mean values are means of nine cheese samples.

$a, b, c$ Les moyennes à un même temps d'affinage suivies de lettres différentes sont significativement différentes $(\mathrm{p}<0,05)$. Les teneurs moyennes représentent la moyenne de neuf échantillons de fromage. 
sed significantly $(P<0.05)$ when $L$ lactis subsp lactis T1 was added to the IFPL starter. Cheeses made with UF milk generally require longer ripening times to achieve maximum grading scores, which is attributed to the lower degree of proteolysis (Bech, 1993). The use of starter strains selected for increasing secondary proteolysis (IFPL starter, Requena et al, 1992), together with the addition of $\mathrm{Lac}^{-} \mathrm{Prt}$ lactococcal strains, produced a significant increase $(P<0.05)$ in amino nitrogen levels from the first month of ripening. Comparison of the results in these cheeses and the results in cheeses made with a commercial starter (Flora Danica) shows that ripening can be accelerated by approximately 1 1/2 months. This finding bears out the results of a previous experiment on evolution of proteolysis in slurries of cheese made from the same milk mixture with a concentrate of the strain T1 (Rodriguez et al, 1996).

\section{Sensory analysis}

The results of sensory analysis of the three cheese batches are shown in table III. The appearance of the cheeses was considered good throughout ripening, with no significant differences between batches $(P<0.05)$. The IFPL cheeses further exhibited remarkably well-distributed interior openings, which have been shown to be the result of growth of the leuconostocs in the cheeses and considered as a valuable characteristic in the appearance scores (Requena et al, 1992). Cheese aroma increased during ripening in all batches, and cheeses made with IFPL starter awarded the best final scores on both aroma and flavour. From 45 days on, the tasting panel found flavour stronger in cheeses made with the IFPL starter and strain T1 than in those made with Flora Danica, the difference becoming more pronounced as ripe-

Table III. Mean values and standard deviation (in parenthesis) for the sensory characteristics of the cheeses during ripening.

Valeurs moyennes et écarts types (entre parenthèses) des caractéristiques sensorielles des fromages au cours de l'affinage.

\begin{tabular}{|c|c|c|c|c|c|c|}
\hline & \multirow{2}{*}{$\begin{array}{c}\text { Cheese } \\
\text { batch }\end{array}$} & \multicolumn{5}{|c|}{ Ripening time (days) } \\
\hline & & 15 & 30 & 45 & 60 & 90 \\
\hline \multirow{3}{*}{ Appearance } & Flora Danica & $3.4(0.8)$ & $3.5(0.9)$ & $3.4(0.5)$ & $4.1(0.8)$ & $3.6(0.7)$ \\
\hline & IFPL & $3.9(0.5)$ & $3.8(0.5)$ & $3.8(0.5)$ & $4.3(0.7)$ & $3.7(0.7)$ \\
\hline & $\mathrm{IFPL}+\mathrm{T} 1$ & $3.6(0.8)$ & $3.8(0.5)$ & $4.0(0.5)$ & $4.6(0.5)$ & $3.9(0.9)$ \\
\hline \multirow{3}{*}{ Aroma } & Flora Danica & $3.3(1.0)$ & $3.7(1.1)$ & $3.6(0.5)$ & $4.5(0.8)$ & $3.8(0.8)$ \\
\hline & IFPL & $2.4(1.0)$ & $3.0(1.0)$ & $3.6(0.5)$ & $4.1(0.7)$ & $4.4(0.5)$ \\
\hline & $\mathrm{IFPL}+\mathrm{T} 1$ & $2.9(1.4)$ & $3.1(0.9)$ & $3.6(0.8)$ & $4.1(0.7)$ & $4.0(0.7)$ \\
\hline \multirow{3}{*}{ Flavour } & Flora Danica & $3.4(0.9)$ & $4.2(0.7)$ & $3.9(0.4)$ & $4.2(0.8)$ & $3.6(0.7)$ \\
\hline & IFPL & $3.0(1.0)$ & $3.3(0.8)$ & $3.4(0.6)$ & $4.3(0.5)$ & $3.9(0.8)$ \\
\hline & $\mathrm{IFPL}+\mathrm{T} 1$ & $2.5(1.0)$ & $3.4(0.8)$ & $3.3(0.7)$ & $4.5(0.5)$ & $3.8(0.8)$ \\
\hline \multirow{3}{*}{ Texture } & Flora Danica & $3.3(0.8)$ & $3.8(0.7)$ & $3.9(0.6)$ & $4.0(0.8)$ & $3.9(0.7)$ \\
\hline & IFPL & $3.5(0.7)$ & $3.6(0.6)$ & $3.7(0.5)$ & $4.1(0.6)$ & $3.9(0.6)$ \\
\hline & $\mathrm{IFPL}+\mathrm{T} 1$ & $3.4(0.9)$ & $3.9(0.7)$ & $3.7(0.5)$ & $4.5(0.8)$ & $3.9(0.5)$ \\
\hline \multirow{3}{*}{$\begin{array}{l}\text { General } \\
\text { acceptance }\end{array}$} & Flora Danica & $3.5(0.9)$ & $4.0(0.8)$ & $3.9(0.9)$ & $4.3(0.9)$ & $4.3(0.9)$ \\
\hline & IFPL & $2.9(0.9)$ & $3.5(0.7)$ & $3.4(0.7)$ & $4.3(0.4)$ & $4.3(0.4)$ \\
\hline & $\mathrm{IFPL}+\mathrm{T} 1$ & $2.9(0.7)$ & $3.6(0.6)$ & $3.3(0.5)$ & $4.4(0.5)$ & $4.4(0.5)$ \\
\hline
\end{tabular}


ning progressed. However, the strong taste of the cheeses was less appreciated by some panel tasters, who made no significant differences between the batches (table III). The texture of all three batches was considered smooth, thanks largely to greater moisture retention, and the panel found this a positive change from the typically hard consistency of low fat cheeses (Drake and Swanson, 1995).

Given optimum flavour development in 2 months and an adequate level of proteolysis, acceptable ripening could be achieved in this time. Some tasters thought that cheeses with the IFPL starter were overripe after 3 months, and even more so where $L$ lactis subsp lactis $\mathrm{T} 1$ had been added.

\section{CONCLUSION}

A reduced fat cheese of acceptable sensory characteristics was successfully made from UF milk concentrate. Moreover, by using a starter culture previously selected as ideal for semi-hard cheese and enhanced by the addition of $\mathrm{Lac}^{-} \mathrm{Prt}$ lactococci, it was possible to shorten the ripening time required in cheeses made with a commercial starter to ensure adequate proteolysis while achieving the typical appearance of such cheeses, with the right balance of flavour and aroma.

\section{ACKNOWLEDGMENTS}

The authors would like to acknowledge financial support for this study from the Comision Interministerial de Ciencia y Tecnología (Project ALI 950046-CO2-01). J Rodriguez is the recipient of a scholarship from the Spanish Council for Scientific Research (CSIC).

\section{REFERENCES}

Ardö $Y$ (1994) Proteolysis and flavour development in reduced fat cheese. Doctoral Thesis, Lund University, Sweden

Ardö Y, Mansson L (1990) Heat treated lactobacilli develop desirable aroma in low-fat cheese. Scand Dairy Info 4, 38-40
Ardỗ Y, Larsson P, Mansson L, Hedelberg A (1989) Studies on peptidolysis during early maturation and its influence on low-fat cheese quality. Milchwissenschaft 44, 485-490

Bech AM (1993) Characterising ripening in UF-cheese. Int Dairy J 3, 329-342

Birkeland SE, Abrahamsen RK, Langsrud T (1992) ACcelerated cheese ripening: use of $\mathrm{Lac}^{-}$mutants of lactococci. J Dairy Res 59, 389-400

Broome MC, Krause DA, Hickey MW (1991) The use of proteinase negative starter and lactobacilli in Cheddar cheese manufacture. Aust J Dairy Technol 46, 6-11

Brulé G, Maubois, JL, Fauquant J (1974) Étude de la teneur en éléments minéraux des produits obtenus lors de l'ultrafiltration du lait sur membrane. Lait 54 , 600-615

Coulson J, Pawlett D, Wivell R (1992) Accelerated ripening of Cheddar cheese. Bull Int Dairy Fed 269, 29-35

De Boer R, Nooy PFC (1980) Low-fat semi-hard cheese from ultrafiltrated milk. North Eur Dairy J 46, 52-61

De Koning PJ, De Boer R, Both P, Nooy PFC (1981) Comparison of proteolysis in a low-fat semi-hard type of cheese manufactured by standard and by ultrafiltration techniques. Neth Milk Dairy J 35, 35-46

De la Fuente MA, Juárez M (1995a) Determination of phosphorus in dairy products by sample wet digestion in a microwave oven. Anal Chim Acta 309, 355-359

De la Fuente MA, Juárez M (1995b) Rapid determination of the $\mathrm{Ca}, \mathrm{Mg}, \mathrm{Na}$ and $\mathrm{K}$ in milk after microwave oven digestion by flame atomic spectrometry. Analyst 120, 107-111

Delbeke R (1987) Experiments on making Saint-Paulin by full concentration of milk with ultrafiltration. Milchwissenchaft 42, 222-225

Drake MA, Swanson BG (1995) Reduced- and low-fat cheese technology: a review. Trends Food Sci Technol 6, 366-369

El-Shibiny S, Mahran GA, Haggag HF, Mahfouz MB, El-Shiekh MM (1991) Accelerated ripening of UF Ras cheese. Egypt J Dairy Sci 19, 25-34

EI Soda M (1993) Accelerated maturation of cheese. Int Dairy J 3, 531-544

El Soda M, Chen C, Riesterer B, Olson N (1991) Acceleration of low-fat cheese ripening using lyophilized extracts of freeze shocked cells of some cheese related microorganisms. Milchwissenchaft 46, 358-360

Emmons DB (1994) Trends in the manufacture of cheese. New varieties. Automation. Yield increase. In: Proc 24th Int Dairy Congr, 18-22 September, Melbourne, Australia

Fontecha J, Peláez C, Juárez M (1994) Biochemical characteristics of a semi-hard ewe's-milk cheese. Z Lebensm Unters Forsch 190, 325-330

Gómez R, Peláez C, De la Torre E (1989) Microbiological study of semi-hard goat's milk cheese (Majorero). Int J Food Sci Technol 24, 147-151

Goudédranche $\mathrm{H}$, Maubois JL, Ducruet $\mathrm{P}$, Mahaut M (1980) Utilization of the new mineral UF membranes for making semi-hard cheeses. Desalination 35. 243-258 
Goudédranche H, Ducruet P, Vachot JC, Pannetier R, Maubois JL (1986) Utilisation du lysozyme en tant qu'agent régulateur de l'affinage en fromagerie. Lait 66, 189-206

Grieve PA, Dulley JR (1983) Use of Streptococcus lactis Lac $^{-}$mutants for accelerating Cheddar cheese ripening. 2 . Their effect on the rate of proteolysis and flavour development. Aust J Dairy Techno/38, 49-54

Holt C (1985) The milk salts: their secretions, concentration and physical chemistry. In: Developments in Dairy Chemistry, vol 3 (PF Fox, ed) Elsevier Applied Science Publishers, London, UK, 143-181

International Dairy Federation (1982) Determination of the total solids content (cheese and processed cheese). FIL-IDF Standard 4A

International Dairy Federation (1985) Milk and milk products. Methods of sampling. FIL-IDF Standard 50B

International Dairy Federation (1986) Détermination de la teneur en matière grasse. FIL-IDF Standard 5B

International Dairy Federation (1987) Sensory evaluation of dairy products. FIL-IDF Standard 99A

Jameson G (1994) Low fat cheese. Quality and technology. In: Proc 24th Int Dairy Congr, 18-22 September, Melbourne, Australia

Kamaly KM, Johnson ME, Marth EH (1989) Characteristics of Cheddar cheese made with mutant strain of lactic streptococci sources of enzymes. Milchwissenschaft 44, 343-346

Kuchroo CN, Fox PF (1982) Soluble nitrogen in Cheddar cheese. Comparison of extraction procedures. Milchwissenschaft 37, 331-335

Kuchroo CN, Rahilly J, Fox PF (1983) Assessment of proteolysis in cheese by reaction with trinitrobenzene sulphonic acid. Ir J Food Sci Technol 7, 129-133

Lelievre J, Lawrence RC (1988) Manufacture of cheese from milk concentrated by ultrafiltration. J Dairy Res $55,465-478$

Martín Hernández C, Juárez M, Ramos M (1992) Biochemical characteristics of three types of goat cheese. J Dairy Sci 75, 1747-1752
McGregor JU, White CH (1990) Effect of enzyme treatment and ultrafiltration on the quality of lowfat Cheddar cheese. J Dairy Sci 73, 571-578

McKay LL, Miller A III, Sandine, WE, Elliker PR (1970) Mechanisms of lactose utilization by lactic acid streptococci: Enzymatic and genetic analyses. J Bacteriol 102, 804-809

Official Methods of Analysis (1975) 12th edn, 16055 (AOAC, ed), Washington, DC, USA

Quiblier JP, Cariou N, Richoux R, Maubois JL (1990) Utilisation du tapioca en technologie pâtes fraîches lissées. Process 1050, 67-72

Qvist KB, Thomsen D, Hoier E (1987) Effect of ultrafiltered milk and use of different starters on the manufacture, fermentation and ripening of Havarti cheese. J Dairy Res 54, 437-446

Requena T, Mckay LL (1993) Plasmid profiles and relationship to lactose utilization/proteinase activity in a lactococcal strain isolated from semi-hard natural cheese. Milchwissenschaft 48, 264-268

Requena T, De la Fuente MA, Fernández de Palencia P, Juárez M, Peláez C (1992) Evaluation of a specific starter for the production of semi-hard goat's milk cheese. Lait 72, 437-448

Rodriguez J, Requena T, Martínez-Castro I, Juárez M (1996) The accelerating effect of a Lactococcus lactis subsp lactis lactose utilization/proteinase deficient strain on proteolysis and flavour development. Z Lebensm Unters Forsch 203, 77-81

Skeie S, Narvhus JA, Abrahamsen RK (1995) Addition of liposome-encapsulated enzymes SP446 and Flavour-zyme to low-fat ( $10 \%$ fat) Gouda-type cheese. Milchwissenchaft 50, 134-138

Spangler $\mathrm{PL}$, EI Soda M, Johnson ME, Olson NF, Amundson CH, Hill CG (1989) Accelerated ripening of Gouda cheese made with ultrafiltered milk using a liposome entrapped enzyme and freeze shocked lactobacilli. Milchwissenchaft 44, 199-203 